TURIZAM

Volume 23, Issue 1

34-52 (2019)

ORIGINAL

SCIENTIFIC PAPER

\title{
Students' Perception of City Branding: The Case of Kastamonu and Kastamonu University
}

\author{
Ömer SaraçA, Hüseyin Pamukçu', Şevki Ulama ${ }^{C}$, Orhan Batman ${ }^{D}$ \\ Received: March 2019 | Accepted: April 2019 \\ DOI: 10.5937/turizam23-20881
}

\begin{abstract}
Recent developments in technology have led to changes in the way we manufacture and the manufacturing volume which allowed for increased competition in the global market. Such competition applies not only to products and businesses, but also to cities, states and destinations. In this context, branding plays an important role in the marketing of cities and states. With its unique natural, historical and cultural assets, Turkey has a number of cities eligible for city branding. Turkish city of Kastamonu, one of the candidates for city branding, boasts a number of cultural assets which drive the tourism sector in the city. The aim of this study was to measure the Kastamonu University, Faculty of Tourism students' perception of city brand associated with the city of Kastamonu. A total number of 505 questionnaires were completed by the university students and the data collected was analyzed using a statistics software suite; frequencies, percentages, means, factor analysis, $t$-test, and one-way analysis of variance (ANOVA) were used for data processing. As a result, a total number of seven dimensions were found with respect to the students' perception of Kastamonu as a city brand. Statistically significant differences were found between parameters such as age and gender of the students, years of academic study, income, place of origin, previous knowledge of the city, first impression of the city and current opinion about the city and these dimensions.
\end{abstract}

Keywords: Marketing, Brand, Branding, City Brand, Kastamonu

A Sakarya Uygulamalı Bilimler University, Tourism Faculty, Tourism Management, Camicedit Neighborhood. Paşa Street. No: 16 Sapanca/Sakarya

B Kastamonu University, Tourism Faculty, Tourism and Hotel Management Cebrail Neighborhood, Aralık Street. No: 15, Kastamonu; Corresponding author: pamukcuhuseyin@gmail.com.

c Sakarya Uygulamalı Bilimler University, Tourism Faculty, Gastronomy and Culinary Arts Department, Camicedit Neighborhood. Paşa Street. No: 16 Sapanca/Sakarya

D Sakarya Uygulamalı Bilimler University, Tourism Faculty, Tourism and Hotel Management, Camicedit Neighborhood. Paşa Street. No: 16 Sapanca/Sakarya 


\section{Introduction}

With the Industrial Revolution, the world entered into a time of great change in the manufacturing style and the production volume. We were introduced to mass production with increased mechanization (Fordism), and the governing manufacturing style of that time catered only to specific needs and demands. Later on, the world changed in a way that consumer needs drew more attention and human-oriented production, sales and marketing has become the key. As a result, a time of competition (post-Fordism) has arrived (Kozak, 2014; Kozak, 2012: 9; Yediyıldız, 1994: 78).

The age of competition opened the doors of the market so a great number of manufacturers; some of which prevailed while others failed as they did not have a flexible corporate structure, and therefore the competitive advantage required for the survival of a company. Today, such competition applies not only to products and businesses but also to cities, states and destinations. Such places which aim for competitive advantage strive for cost advantage and differentiation in the face of the competition using their assets and abilities (Porter, 1985).

In this context, branding plays an important role in the marketing of cities and states. The reason behind this statement is the fact that cities need to create an image in people's minds, and an identity, a logo and a slogan which will resonate with such mental image if it is for them to claim the market share they deserve. The concept of 'city brand' was born in the light of these factors and it affects the people's decision to invest in, move to, work in and travel to a certain place (Kotler, Gertner, 2002: 249-261; Özdemir, Karaca, 2009:118; Yüksel Avcılar, Kara, 2015; Erdoğan, 1996, 51).

With its unique natural, historical and cultural heritage, Turkey has a number of cities eligible for city branding. One of these cities, Kastamonu, boasts a total number of 564 immovable cultural assets. Many of these cultural assets are branded as "Kastamonu Mansions" (URL-1, 2017) with their distinctive architectural features such as facades with motifs. There is no doubt that architectural assets play an important role in city branding (Manic, Backovic, 2010; Garaca et al., 2011). In addition, local dishes such as the traditional meat buns, banduma, einkorn wheat meal, sour rice meal, and Taşköprü garlic, and influential people from the city such as Şaban-1 Veli, Şerife Bacı and Sgt. Halime also play an important role in city branding of Kastamonu. Moreover, thanks to the opportunity now offered by to local businesses to the tourists to watch how ground halva is made using authentic techniques, this type of halva has become yet another cultural asset adding value to Kastamonu.

With the influence of the university located in the city, Kastamonu makes progress in the way to become a city brand with its increasing number of recreational venues, its booming local economy thanks to the increasing number of university students, and therefore the increasing amount of investment, employment ratio and dynamism which is backed by innovative landscaping efforts. In this context, university students play an important role in Kastamonu's progress in the way to become a city brand along with the aforementioned touristic assets and the supporting infrastructure and superstructure. This study aimed to measure the Faculty of Tourism students' perception of city branding of Kastamonu. 


\section{Literature}

\section{Brand, the Concept of Brand Image and City Branding}

A brand is associated with creation of value, i.e. "added value," in an organization. The term can be defined as the sum of the efforts made by a group of sales personnel to differentiate a product or a service from the competition. Such efforts include a number of rational, tangible, visual, and auditory aspects such as catchphrases, colors, logos and slogans (Avcllar, Varinli, 2013; Aaker, 2009; İlgüner, 2006).

Brand image, on the other hand, is associated with the consumers' feelings, opinions, beliefs about and perception of a certain brand. Created as a result of consumers' impressions, brand image reveals the public perception about an organization when compared to its competition. Positive and negative qualities of a product, its strengths and weaknesses, are processed to create the brand image (Özdemir, Karaca, 2009:117; Perry, Wisnom, 2003:15). Brand image, in this context, acts as a guide to city branding.

City branding is the application of the strategies-commonly used in product brandingat an urban level. In this context, a city aims to differentiate itself from other cities using its natural, cultural, historic, and social features supported by certain symbols and slogans. Thus, cities become specialized at a rational and emotional level (Peker, 2006: 21; Banger, 2006:15). Another definition of the term suggests that city branding is the sum of the efforts aimed at making a city attractive for the people for residential, occupational, educational, economic, and touristic purposes using branding techniques and strategies, as opposed to the public perception of an unexceptional city. Accordingly, the city will be distinguished from the others and it will be more often preferred when compared to its competition (Dinnie, 2011:7; Ailawadi, Keller, 2004: 334).

A closer look into the literature shows that Altunbaş (2007) underlined the importance of city branding efforts and the author made some suggestions about the marketing communication which needs to be used. Avcllar, Kara (2009) explored the city branding methods and commonly used marketing strategies. Merrilees, Miller and Herington (2009) analyzed the case of Gold Coast City, Australia. The authors, as part of their survey analysis, reported the brand perception of the Locals and the key factors affecting such perception. Kavaratzis (2009) designed a case study for Amsterdam and Budapest and explored urban planning and city branding in this context. Tek (2009) analyzed the "Brand City" project which was brought about with the Turkish Tourism Strategy (2023), and revealed the shortcomings and weaknesses of this project. Ceylan (2011) studied the brand image of Pamukkale, a touristic destination in Turkey, and reported the perceived brand image of tourists visiting this destination based on their gender and their accommodation choices. Cevher (2012) explored a theoretical framework for city branding and suggested its positive impact at a regional level. Can, Kazancl, Başaran (2014) aimed to measure the perceived city image of the Turkish city of Rize and its dwellers both in terms of their tangible and intangible characteristics. Güler and Gürer (2015) focused on the relationship between local participation trends and commitment to the 'brand city' concept in the Turkish city of Nevşehir. Moreover, the authors attempted to identify the factors influencing the commitment to the 'brand city' concept and the variables associated with the attractiveness of this city. Firat and Kömürcüoğlu (2015) explored the city image of the Turkish province of Muğla as perceived by the students of Muğla Sitkı Koçman University. 


\section{Purpose of City Branding and the City Branding Process}

In today's globalized world, survival of states in the global marketplace depends on the consumer preferences. In this context, city branding protects the states from going into a price-oriented competition (Özdemir, Karaca, 2009: 118). The reason behind such protection is the fact that branding has a significant effect on consumers' decision to visit a city, to purchase products originating from that city, to invest in a business in that city, and even to move to that city (Anholt, 2005:18).

Accordingly, the purpose of city branding is to attract more tourists and investors which will add value to the city with their economic activities and investments, respectively. The main purpose, on the other hand, is to ensure economic growth and therefore to offer a better and happier life for the people (URL-2, 2017).

There are a number of city brands built on these principles. While the Turkish city of Antalya assumed a city brand based on the Sun, the sea and golden sands, cities such as Kyrenia and Las Vegas are identified with casino tourism. Cities of Rome and Istanbul are associated with cultural tourism, while Paris reminds people of romanticism and the Eiffel Tower and these cities attract visitors with the image they created.

When compared to product branding, city branding is a much more complicated and difficult pursuit. The reason behind this is that city branding requires creation of an image for both tangible and intangible assets including natural resources, touristic potential, infrastructure and superstructure, local businesses and the locals (Avc1lar, Kara, 2015: 77-78). In order to be able to know "where we stand" in this process, we need to analyze the outskirts of the city, city center and the stakeholders involved and to clearly define the strengths and weaknesses, opportunities and risks available (Ülgen, Mirze, 2006:116).

Some suggested that the branding process needs to find an answer to the question, "Which feature of the city, an important feature for the target audience, distinguish the city from others?" In light of this question, we can define the branding process as the identification of the distinct characteristics of a city and the development of a marketing strategy accordingly (Saran, 2005).

In this context, we can say that it is a must to create an identity, an image, a logo, a symbol and a slogan for the city as part of the city branding process.

A city's identity involves establishing an outlook for the city as part of the branding process and making efforts accordingly (İslamoğlu, 2002:56); city image, on the other hand, involves communication of the characteristic features of the city to promote a certain perception in the audience, therefore making a difference in the face of its competition (Rainisto, 2003: 24). The logo and symbol are the visuals attached to the brand. These are the designs prepared using authentic shapes, objects, themes, characters, letters or words in order to ensure that the brand is memorable. Slogan is the catchphrase identified with the brand. It adds meaning to the brand name and symbol as part of the brand positioning and strategy development efforts. In order for a slogan to be effective, it needs to be relevant, interesting, allegorical and catchy (Tek, 2005).

Among the literature reports, Yuen (2005) explored the case of Singapore and suggested that the cultural heritage of a city plays a very important role in creating the identity of that city. Özdemir and Karaca (2009) focused on a city brand image with respect to the requirements and dimensions of city branding. İri, İnal and Türkmen (2011) underlined the importance of promotion and recognition in city brand creation process. Kaypak (2013) investigated the need for city branding in the globalized world and explored the social, economic and cultural impact of city branding. Paunović (2014) performed statistical tests in order to analyze the factors influencing brand loyalty in Serbia. Authors reported a number of suggestions for the creation of national and regional target marketing strategies. 


\section{Method}

This study aimed to measure the Kastamonu University students' perception of city branding of Kastamonu. We decided to use the sampling method, as it was impossible to reach out to all the students of Kastamonu University, and non-random sampling was used. In non-random sampling, the participants are selected among a pool of correspondents from which the researchers believe they will find the answer to a research problem (Coşkun et al., 2017: 149).

The Faculty of Tourism was selected as the sampling group. The most important reason behind this selection was that the assets and abilities which constitute the perceived city brand of Kastamonu are closely associated with touristic activities in the city. Thus, we envisioned that it would be important to measure the city brand of Kastamonu as perceived by the students of the Faculty of Tourism.

In this context, data was obtained from a total number 589 Faculty of Tourism students during the academic year of 2017-18 using the survey method. A part of the data was collected during the exam sessions. And the rest of the data was collected using an online survey which was sent to the students via email. However, it was not possible to collect a round number of completed surveys as some of the students were not actively attending to the classes during the academic year and some of the students were not Turkish speakers and they reported their inability to fill out the questionnaire which was in Turkish.

Using the convenience sampling method, the questionnaires collected between the dates of 10.13.2017 and 05.22.2018. The questionnaire comprised of two sections. The first section included a total number of 9 questions aimed at collecting demographics data of the participants and measuring their thoughts about the city. The second section included a total number of 40 statements prepared using the Merrilees, Miller and Herington (2009) and Cop and Akpinar (2014) studies on measuring the perceived city brand and the statements were organized in a 5-point Likert scale.

Among the completed questionnaires, 18 were excluded as they had data errors; a total number of 505 questionnaires were then analyzed using SPSS software suite. We believe that the total number of 505 questionnaires included in this study was sufficient to achieve the purpose of this study. Moreover, it is commonly accepted that the number of questionnaires included should at least be equal to ten times the number of statements in the questionnaire. In this context, the number of completed questionnaires included to this study, i.e. 505, was more than the suggested 10x the number of statements, i.e. 40o, (Kerlinger, 1978; Hair et al., 1998; Kline, 2011) and the fact that the number representing the infinite universe, i.e. 384 , was exceeded showed the reliability of this study (Kozak, 2014).

A reliability test was performed in order to measure the internal consistency of the scale. In this context, Cronbach's Alpha is the most commonly used and trusted measure. Table 1 shows the reliability of our scale.

Table 1. Reliability Test

\begin{tabular}{|c|c|}
\hline Cronbach's Alpha & Item Counts \\
\hline 0.934 & 40 \\
\hline
\end{tabular}

A closer look at the Table 1 shows that the reliability of the city brand scale was 0.934 as found using Cronbach's Alpha measure, and this was a rather high level of reliability.

Furthermore, we used factor analysis to confirm the construct validity of the scale. Kaiser-Meyer-Olkin (KMO) and Bartlett's tests are used to see if the data obtained is suitable for Explorato- 
ry Factor Analysis (Çokluk et al., 2012; Büyüköztürk, 2010; Karagöz, Kösterelioğlu, 2008). Higher KMO values signify that each variable of the scale can be estimated by the other variables of the scale at a high level of accuracy. In cases where the KMO values are equal to or in close proximity of zero, it is impossible to comment on the correlation as the distribution is disorderly. If the KMO test result is lower than 0.50 , then it can be said that factor analysis cannot be performed on this dataset (Çokluk et al., 2012: 207; Field, 2000). Accordingly, we expected to obtain statistically significant results from Bartlett's test and a result higher than 0.50 from KMO test. Table 2 shows the results of Bartlett's test and KMO test for the sample size of this study.

Table 2. KMO and Barlett's Test

\begin{tabular}{|l|l|c|}
\hline \multicolumn{2}{|l|}{ Kaiser-Meyer-Olkin Measure of Sampling Adequacy. } & .930 \\
\hline \multirow{3}{*}{$\begin{array}{l}\text { Bartlett's Test of } \\
\text { Sphericity }\end{array}$} & Approx. Chi-Square & 11686.108 \\
\cline { 2 - 3 } & df & 780 \\
\cline { 2 - 3 } & Sig. & .000 \\
\hline
\end{tabular}

As shown in Table 2, KMO value was found to be 0.930, which suggests that the sample size was "perfect" for the factor analysis (Çokluk et al., 2012: 207). Nevertheless, a closer look at the results of Bartlett's test showed that the chi-square value found was statistically significant. Table 3 shows the results of factor analysis.

Table 3. Factor Headings, Factors' Reliability Test Results, Item Counts, Cumulative Values of the Variance Explained

\begin{tabular}{|c|c|c|c|c|}
\hline Factors & Factors Headings & Cronbach's Alpha & Item Counts & Cumulative Variance \\
\hline 1 & $\begin{array}{l}\text { Plans, Recommenda- } \\
\text { tions and Awareness } \\
\text { about the City }\end{array}$ & 0.937 & 13 & 18,870 \\
\hline 2 & $\begin{array}{l}\text { Expectations from the } \\
\text { Local Government }\end{array}$ & 0.812 & 5 & 29.556 \\
\hline 3 & $\begin{array}{l}\text { Event Organizations } \\
\text { and Shopping Options } \\
\text { in the City }\end{array}$ & 0.861 & 7 & 38.173 \\
\hline 4 & $\begin{array}{l}\text { Support in City } \\
\text { Branding }\end{array}$ & 0,873 & 5 & 45.846 \\
\hline 5 & Locals & 0,866 & 4 & 52.820 \\
\hline 6 & $\begin{array}{l}\text { Natural Characteristic } \\
\text { and Culture of the City }\end{array}$ & 0.826 & 3 & 58.297 \\
\hline 7 & City Planning & 0,788 & 3 & 63,719 \\
\hline
\end{tabular}

In accordance with the factor analysis as shown in Table 3, 1 statement out of 41 statements was excluded and a final number of 40 statements and 7 factors were used. In determining the number of factors, eigenvalue dimensioning method was used. When the variable number is 20-50, size determination according to eigenvalue gives reliable results (Coşkun et al., 2017: 280). It was further found that these factors accounted for $63.719 \%$ of the variance. The reason behind the exclusion of one of the statements was that it had low factor loading and that it was listed under more than one factors. According to the literature criteria, a statement is excluded if its factor loading is lower than 0.45 and if it is listed under more than one factors with a factor loading difference less than 0.10 (Balc1,1995:142-143; Büyüköztürk, 2002:118-119). 
Frequency, percentage, means and standard deviation tests were performed in this study in order to form arguments about the demographics of the participants and their opinions about the city. Then, we conducted comparative analyses in order to find statistically significant differences between the demographics of the participants and their opinions about the city using the factors obtained from the factor analysis. Here, we used t-test and one-way analysis of variance (ANOVA).

\section{Findings}

\section{Demographics of the Participants/Students}

Table 4 shows the demographic data about the participants of this study, i.e. Kastamonu University, Faculty of Tourism students, including their gender, age, region of origin, residence, income, and years of higher education.

Table 4. Distribution of Demographics of the Participants/Students

\begin{tabular}{|c|c|c|c|c|c|}
\hline Gender & Frequency & $\%$ & Settlement & Frequency & $\%$ \\
\hline Female & 233 & 46.1 & Province & 258 & 51.1 \\
\hline Male & 263 & 52.1 & County & 154 & 30.5 \\
\hline Missing data & 9 & 1.8 & Village & 86 & 17 \\
\hline Total & 505 & 100 & Missing data & 7 & 1.4 \\
\hline Age & Frequency & $\%$ & Total & 505 & 100 \\
\hline $18-20$ & 189 & 37.4 & Income & Frequency & $\%$ \\
\hline $21-23$ & 240 & 47.5 & $1000 \mathrm{TL}$ and under & 128 & 25.3 \\
\hline 24 and above & 73 & 14.5 & $1001-1500 \mathrm{TL}$ & 111 & 22 \\
\hline Missing data & 3 & 0.6 & $1501-2000 \mathrm{TL}$ & 77 & 15.2 \\
\hline Total & 505 & 100 & 2001- $2500 \mathrm{TL}$ & 54 & 10.7 \\
\hline Geographical Region & Frequency & $\%$ & $2501 \mathrm{TL}$ and above & 133 & 26.3 \\
\hline Marmara Region & 86 & 17 & Missing data & 2 & 0.4 \\
\hline Black Sea region & 171 & 33.9 & Total & 505 & 100 \\
\hline Central Anatolia Region & 80 & 15.8 & Grade & Frequency & $\%$ \\
\hline Aegean Region & 52 & 10.3 & 1st grade & 102 & 20.2 \\
\hline Mediterranean Region & 42 & 8.3 & 2 nd grade & 149 & 29,5 \\
\hline Eastern Anatolia Region & 22 & 4.4 & 3rd grade & 111 & 22 \\
\hline Southeastern Anatolia Region & 21 & 4.2 & 4 th grade & 119 & 23.6 \\
\hline Missing data & 31 & 6.1 & Graduate & 24 & 4.8 \\
\hline Total & 505 & 100 & Total & 505 & 100 \\
\hline
\end{tabular}

A closer look at Table 4 shows that $52.1 \%$ of the participants were male $(n=263)$, and $47.5 \%$ of the participants were 21 to 23 years old $(n=240)$. In terms of region of origin, $33.9 \%$ of the participants were from the Black Sea Region $(n=171)$, and $51.1 \%$ lived in urban areas $(n=258)$. A closer look at their income level showed that $26.3 \%$ of the participants reported an income level of 
$£ 2501$ or more $(\mathrm{n}=133)$ and $25.3 \%$ of the participants reported an income level of $£ 1000$ or less $(n=128)$. Finally, $29.5 \%$ of the participants were studying their second year in university $(n=149)$.

\section{Students' Opinions about the City}

This section explores the information Kastamonu University, Faculty of Tourism students had about the city before their first visit to the city, their first impression about the city and their current opinion about the city. Table 5 represents the distribution of responses collected in this respect.

Table 5. Distribution of Students' Opinions about the City

\begin{tabular}{|c|c|c|c|c|c|c|c|c|}
\hline $\begin{array}{l}\text { About the city } \\
\text { before their first } \\
\text { visit to the city }\end{array}$ & Frequency & $\%$ & $\begin{array}{c}\text { Their first } \\
\text { impression about } \\
\text { the city }\end{array}$ & Frequency & $\%$ & $\begin{array}{c}\text { Their current } \\
\text { opinion about the } \\
\text { city }\end{array}$ & Frequency & $\%$ \\
\hline Yes & 229 & 45.3 & Positive & 241 & 47.7 & Positive & 320 & 63.4 \\
\hline No & 276 & 54.7 & Negative & 264 & 52.3 & Negative & 185 & 36.6 \\
\hline Total & 505 & 100 & Total & 505 & 100 & Total & 505 & 100 \\
\hline
\end{tabular}

Table 5 shows that $54.7 \%$ of the participants $(\mathrm{n}=276)$ did not have any information about the city before their first visit; $52.3 \%$ of the participants $(n=264)$ had a negative first impression of the city and $63.4 \%$ of the participants $(n=320)$ had a positive opinion about the city at the time of the survey.

\section{Factor Analysis}

This section includes the factor analysis of the scale. Table 6 shows the factors developed with respect to the perceived city brand of the participants, i.e. Kastamonu University, Faculty of Tourism students.

Table 6. Perception Scale of Cities for Branding

\begin{tabular}{|c|c|c|c|c|c|c|c|}
\hline \multirow{2}{*}{ Items } & \multicolumn{7}{|c|}{ Factors } \\
\hline & Fac. 1 & Fac. 2 & Fac. 3 & Fac. 4 & Fac. 5 & Fac. 6 & Fac. 7 \\
\hline Q9: I would recommend moving to this city to the people I know & .790 & & & & & & \\
\hline Q5: It is a privilege to live in this city, & .784 & & & & & & \\
\hline Q4: I would like to work in this city & .781 & & & & & & \\
\hline Q1: I could live in this city after I get my degree & .732 & & & & & & \\
\hline Q13 I would recommend visiting this city to the people I know & .721 & & & & & & \\
\hline $\begin{array}{l}\text { Q12: I would recommend working in this city to the people I } \\
\text { know }\end{array}$ & .705 & & & & & & \\
\hline Q3: I would like to spend my holiday here & .679 & & & & & & \\
\hline Q6: This city offers a good lifestyle & .678 & & & & & & \\
\hline Q2: I would like to visit this city after I get my degree & .676 & & & & & & \\
\hline $\begin{array}{l}\text { Q11: I would recommend having a holiday in this city to the } \\
\text { people I know }\end{array}$ & .676 & & & & & & \\
\hline $\begin{array}{l}\text { Q10: I would recommend studying in this city to the people I } \\
\text { know }\end{array}$ & .651 & & & & & & \\
\hline
\end{tabular}




\begin{tabular}{|c|c|c|c|c|c|c|c|}
\hline \multirow{2}{*}{ Items } & \multicolumn{7}{|c|}{ Factors } \\
\hline & Fac. 1 & Fac. 2 & Fac. 3 & Fac. 4 & Fac. 5 & Fac. 6 & Fac. 7 \\
\hline Q8: I think this city has a city brand & .639 & & & & & & \\
\hline Q7: This city has distinctive features when compared to others & .575 & & & & & & \\
\hline Q24: There are sufficient shopping centers in this city & & .783 & & & & & \\
\hline Q25: There are many high-end stores in this city & & .774 & & & & & \\
\hline Q22: There are arts events in this city & & .703 & & & & & \\
\hline Q20: There are sufficient entertainment venues in this city & & .665 & & & & & \\
\hline Q23: There are sufficient sports venues in this city & & .651 & & & & & \\
\hline Q14: There are sufficient shopping options in this city & & .628 & & & & & \\
\hline Q21: There are sufficient dining options in this city & & .579 & & & & & \\
\hline Q27: I make an effort for positive presentation of this city & & & .761 & & & & \\
\hline Q29: I would like to contribute to the development of this city & & & .753 & & & & \\
\hline Q28: I inform the people I know about this city & & & .737 & & & & \\
\hline $\begin{array}{l}\text { Q30: I would like to play my part in the development of this } \\
\text { city }\end{array}$ & & & .710 & & & & \\
\hline Q26: I support the branding of this city & & & .619 & & & & \\
\hline $\begin{array}{l}\text { Q18: Urban transportation options of the city should be } \\
\text { improved }\end{array}$ & & & & .795 & & & \\
\hline Q17: Urban cleanliness of the city should be improved & & & & .790 & & & \\
\hline Q16: Cultural amenities of the city should be improved & & & & .755 & & & \\
\hline Q15: Social amenities of the city should be improved & & & & .684 & & & \\
\hline Q19: Promotion efforts of the city should be improved & & & & .615 & & & \\
\hline Q32: Locals are amicable towards outsiders & & & & & .817 & & \\
\hline Q31: Locals are kind people & & & & & .768 & & \\
\hline Q34: It is easy to communicate with the locals & & & & & .701 & & \\
\hline Q33: Locals care for the development of the city & & & & & .700 & & \\
\hline Q40: Urban transportation works smoothly & & & & & & .807 & \\
\hline Q39: Pavements of this city are well-kept & & & & & & .724 & \\
\hline Q41: Streets of the city are well-organized & & & & & & .719 & \\
\hline Q36: This city is known for its natural beauty & & & & & & & .774 \\
\hline Q35: This city has beautiful natural characteristics & & & & & & & .769 \\
\hline $\begin{array}{l}\text { Q37: The city has a rich tangible cultural heritage with mosques, } \\
\text { madrasas, social complexes, etc. from the Ottoman period }\end{array}$ & & & & & & & .660 \\
\hline
\end{tabular}

\section{Comparative Analyses of the City Brand Dimensions and Demographics and Opinions About the City as Reported by the Students}

In this section, we performed t-test and one-way analysis of variance (ANOVA) in order to identify the distribution of demographics of the participants, i.e. Kastamonu University, Faculty of Tourism students, and their opinions about the city and city branding dimensions.

Table 7 shows the correlation between gender and city brand dimensions. 
Table 7. T-test Results Between Factors and Gender

\begin{tabular}{|c|c|c|c|c|}
\hline Factors Headings & Gender & $\mathrm{n}$ & Mean & $\mathrm{P}$ \\
\hline \multirow{2}{*}{$\begin{array}{l}\text { Plans, Recommendations and Awareness about } \\
\text { the City }\end{array}$} & Female & 233 & 2.6916 & \multirow{2}{*}{0.247} \\
\hline & Male & 263 & 2.7900 & \\
\hline \multirow{2}{*}{ Expectations from the Local Government } & Female & 233 & 4.1090 & \multirow{2}{*}{0.017} \\
\hline & Male & 263 & 3.9194 & \\
\hline \multirow{2}{*}{$\begin{array}{l}\text { Event Organizations and Shopping Options in } \\
\text { the City }\end{array}$} & Female & 233 & 2.2305 & \multirow{2}{*}{0.000} \\
\hline & Male & 263 & 2.6315 & \\
\hline \multirow{2}{*}{ Support in City Branding } & Female & 233 & 3.6146 & \multirow{2}{*}{0.608} \\
\hline & Male & 263 & 3.5686 & \\
\hline \multirow{2}{*}{ Locals } & Female & 233 & 2.8155 & \multirow{2}{*}{0.031} \\
\hline & Male & 263 & 3.0190 & \\
\hline \multirow{2}{*}{ Natural Characteristic and Culture of the City } & Female & 233 & 3.9900 & \multirow{2}{*}{0.001} \\
\hline & Male & 263 & 3.6844 & \\
\hline \multirow{2}{*}{ City Planning } & Female & 233 & 3.0215 & \multirow{2}{*}{0.408} \\
\hline & Male & 263 & 2.9449 & \\
\hline
\end{tabular}

A closer look at the Table 7 showed a statistically significant difference between the participants' gender and the dimensions of "Expectations from the Local Government" and "Natural Characteristic and Culture of the City." It was found that female participants had a positive perception about these dimensions. Furthermore, another statistically significant difference was found between the participants' gender and the dimensions of "Event Organizations and Shopping Options in the City" and "Locals." Here, it was found that male participants had a positive perception about these dimensions.

Table 8 shows the correlation between student's knowledge about the city and city brand dimensions.

Table 8. T-test Results Between Factors and City Information and Thoughts

\begin{tabular}{|c|c|c|c|c|c|}
\hline Factors & \multicolumn{2}{|l|}{ Questions about City } & $\mathrm{n}$ & Mean & $\mathrm{P}$ \\
\hline \multirow{6}{*}{$\begin{array}{l}\text { Plans, Recommendations } \\
\text { and Awareness about the } \\
\text { City }\end{array}$} & \multirow{2}{*}{ About the city before their first visit to the city } & Yes & 229 & 2.9325 & \multirow{2}{*}{0.000} \\
\hline & & No & 276 & 2.6056 & \\
\hline & \multirow{2}{*}{ Their first impression about the city } & Positive & 241 & 3.1162 & \multirow{2}{*}{0.000} \\
\hline & & Negative & 264 & 2.4231 & \\
\hline & \multirow{2}{*}{ Their current opinion about the city } & Positive & 320 & 3.1647 & \multirow{2}{*}{0.000} \\
\hline & & Negative & 185 & 2.0432 & \\
\hline \multirow{6}{*}{$\begin{array}{l}\text { Expectations from the Local } \\
\text { Government }\end{array}$} & \multirow{2}{*}{ About the city before their first visit to the city } & Yes & 229 & 4.0026 & \multirow{2}{*}{0.888} \\
\hline & & No & 276 & 4.0138 & \\
\hline & \multirow{2}{*}{ Their first impression about the city } & Positive & 241 & 3.9386 & \multirow{2}{*}{0.880} \\
\hline & & Negative & 264 & 4.0727 & \\
\hline & \multirow{2}{*}{ Their current opinion about the city } & Positive & 320 & 3.9837 & \multirow{2}{*}{0.404} \\
\hline & & Negative & 185 & 4.0519 & \\
\hline
\end{tabular}




\begin{tabular}{|c|c|c|c|c|c|}
\hline Factors & \multicolumn{2}{|l|}{ Questions about City } & $\mathrm{n}$ & Mean & $\mathrm{P}$ \\
\hline \multirow{6}{*}{$\begin{array}{l}\text { Event Organizations and } \\
\text { Shopping Options in the } \\
\text { City }\end{array}$} & \multirow{2}{*}{ About the city before their first visit to the city } & Yes & 229 & 2.5459 & \multirow{2}{*}{0.510} \\
\hline & & No & 276 & 2.3834 & \\
\hline & \multirow{2}{*}{ Their first impression about the city } & Positive & 241 & 2.6762 & \multirow{2}{*}{0.000} \\
\hline & & Negative & 264 & 2.2570 & \\
\hline & \multirow{2}{*}{ Their current opinion about the city } & Positive & 320 & 2.6543 & \multirow{2}{*}{0.000} \\
\hline & & Negative & 185 & 2.1158 & \\
\hline \multirow{6}{*}{ Support in City Branding } & \multirow{2}{*}{ About the city before their first visit to the city } & Yes & 229 & 3.5930 & \multirow{2}{*}{0.970} \\
\hline & & No & 276 & 3.5897 & \\
\hline & \multirow{2}{*}{ Their first impression about the city } & Positive & 241 & 3.6830 & \multirow{2}{*}{0.046} \\
\hline & & Negative & 264 & 3.5074 & \\
\hline & \multirow{2}{*}{ Their current opinion about the city } & Positive & 320 & 3.7969 & \multirow{2}{*}{0.000} \\
\hline & & Negative & 185 & 3.2354 & \\
\hline \multirow{6}{*}{ Locals } & \multirow{2}{*}{ About the city before their first visit to the city } & Yes & 229 & 3.0033 & \multirow{2}{*}{0.201} \\
\hline & & No & 276 & 2.8832 & \\
\hline & \multirow{2}{*}{ Their first impression about the city } & Positive & 241 & 3.2853 & \multirow{2}{*}{0.000} \\
\hline & & Negative & 264 & 2.6203 & \\
\hline & \multirow{2}{*}{ Their current opinion about the city } & Positive & 320 & 3.2383 & \multirow{2}{*}{0.000} \\
\hline & & Negative & 185 & 2.4176 & \\
\hline \multirow{6}{*}{$\begin{array}{l}\text { Natural Characteristic and } \\
\text { Culture of the City }\end{array}$} & \multirow{2}{*}{ About the city before their first visit to the city } & Yes & 229 & 3.8646 & \multirow{2}{*}{0.404} \\
\hline & & No & 276 & 3.7899 & \\
\hline & \multirow{2}{*}{ Their first impression about the city } & Positive & 241 & 3.9502 & \multirow{2}{*}{0.007} \\
\hline & & Negative & 264 & 3.7083 & \\
\hline & \multirow{2}{*}{ Their current opinion about the city } & Positive & 320 & 4.0177 & \multirow{2}{*}{0.000} \\
\hline & & Negative & 185 & 3.4883 & \\
\hline \multirow{6}{*}{ City Planning } & \multirow{2}{*}{ About the city before their first visit to the city } & Yes & 229 & 3.0902 & 0.51 \\
\hline & & No & 276 & 2.9100 & 1 \\
\hline & Their firct imoreccion a hout the citv & Positive & 241 & 3.2407 & 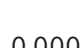 \\
\hline & 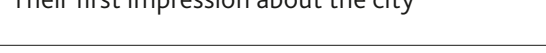 & Negative & 264 & 2.7645 & 0.000 \\
\hline & Their current onininn about the citv & Positive & 320 & 3.2062 & 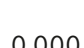 \\
\hline & Ineir current opinion about tne city & Negative & 185 & 2.6207 & 0.000 \\
\hline
\end{tabular}

A closer look at the Table 8 showed a statistically significant difference between students' "knowledge about the city before visiting the city" and the dimension of "Plans, Recommendations and Awareness about the City." In this context, the participants whose response to this question was "Yes" are found to have a positive perception about this dimension. Statistically significant differences were found between "first impression about the city" and "current opinion about the city," and the dimensions of "Plans, Recommendations and Awareness about the City," "Event Organizations and Shopping Options in the City," "Support in City Branding," "Locals," "Natural Characteristic and Culture of the City," and "City Planning." In this context, it was found that the students who provided positive responses had a more positive perception about these dimensions.

Table 9 shows the correlation between student's demographics and city brand dimensions. 
Table 9. One-way Analysis (ANOVA) of Variance Between Factors and Demographic Characteristics

\begin{tabular}{|c|c|c|c|}
\hline \multirow{2}{*}{ Factors } & \multirow{2}{*}{ Demographic questions } & \multicolumn{2}{|c|}{ ANOVA } \\
\hline & & $\mathrm{F}$ & Sig. \\
\hline \multirow{5}{*}{ Plans, Recommendations and Awareness about the City } & Age & 13.482 & 0.000 \\
\hline & Grade & 5.425 & 0.000 \\
\hline & Income & 1.855 & 0.117 \\
\hline & Settlement & 1.100 & 0.334 \\
\hline & Geographical Region & 3.079 & 0.006 \\
\hline \multirow{5}{*}{ Expectations from the Local Government } & Age & 19.833 & 0.000 \\
\hline & Grade & 8.869 & 0.000 \\
\hline & Income & 2.448 & 0.046 \\
\hline & Settlement & 0.308 & 0.735 \\
\hline & Geographical Region & 0.645 & 0.694 \\
\hline \multirow{5}{*}{ Event Organizations and Shopping Options in the City } & Age & 2.980 & 0.052 \\
\hline & Grade & 3.953 & 0.004 \\
\hline & Income & 3.678 & 0.006 \\
\hline & Settlement & 0.877 & 0.417 \\
\hline & Geographical Region & 2.261 & 0.037 \\
\hline \multirow{5}{*}{ Support in City Branding } & Age & 28.370 & 0.000 \\
\hline & Grade & 10.874 & 0.000 \\
\hline & Income & 0.478 & 0.752 \\
\hline & Settlement & 1.054 & 0.349 \\
\hline & Geographical Region & 1.507 & 0.174 \\
\hline \multirow{5}{*}{ Locals } & Age & 0.056 & 0.946 \\
\hline & Grade & 2.347 & 0.054 \\
\hline & Income & 1.499 & 0.201 \\
\hline & Settlement & 0.302 & 0.740 \\
\hline & Geographical Region & 0.969 & 0.445 \\
\hline \multirow{5}{*}{ Natural Characteristic and Culture of the City } & Age & 24.750 & 0.000 \\
\hline & Grade & 8.882 & 0.000 \\
\hline & Income & 1.098 & 0.357 \\
\hline & Settlement & 2.580 & 0.077 \\
\hline & Geographical Region & 0.877 & 0.512 \\
\hline \multirow{5}{*}{ City Planning } & Age & 0.308 & 0.735 \\
\hline & Grade & 1.797 & 0.128 \\
\hline & Income & 1.497 & 0.202 \\
\hline & Settlement & 0.042 & 0.959 \\
\hline & Geographical Region & 2.093 & 0.053 \\
\hline
\end{tabular}

A closer look at the Table 9 showed statistically significant differences between demographics of the students and some of the city brand dimensions. Here, we performed Games-Howell test for the variables with variances less than 0.05 , and Tukey test for those higher than 0.05 . 
Table 10 shows the ANOVA distribution of student's demographics and city brand dimensions.

Table 10. One-Way Variance Analysis (ANOVA) Between Factors and Demographic Characteristics (Tukey-Games Howel)

\begin{tabular}{|c|c|c|c|c|}
\hline \multicolumn{2}{|l|}{ Age } & $\mathrm{n}$ & Mean & Homogeneity of Variances Sig. \\
\hline \multirow{3}{*}{$\begin{array}{l}\text { Plans, Recommendations and } \\
\text { Awareness about the City }\end{array}$} & $18-20$ & 189 & 2.685 & \multirow{3}{*}{ e0.029 } \\
\hline & $21-23$ & 240 & 2.651 & \\
\hline & 24 and above & 73 & 3.274 & \\
\hline \multirow{3}{*}{$\begin{array}{l}\text { Expectations from the Local } \\
\text { Government }\end{array}$} & $18-20$ & 189 & 4.041 & \multirow{3}{*}{0.000} \\
\hline & $21-23$ & 240 & 3.815 & \\
\hline & 24 and above & 73 & 4.528 & \\
\hline \multirow[b]{3}{*}{ Support in City Branding } & $18-20$ & 189 & 3.564 & \multirow{3}{*}{0.401} \\
\hline & $21-23$ & 240 & 3.383 & \\
\hline & 24 and above & 73 & 4.326 & \\
\hline \multirow{3}{*}{$\begin{array}{l}\text { Natural Characteristic and Culture } \\
\text { of the City }\end{array}$} & $18-20$ & 189 & 3.850 & \multirow{3}{*}{0.000} \\
\hline & $21-23$ & 240 & 3.598 & \\
\hline & 24 and above & 73 & 4.497 & \\
\hline \multicolumn{2}{|l|}{ Grade } & $\mathrm{n}$ & Mean & Homogeneity of Variances Sig. \\
\hline \multirow{5}{*}{$\begin{array}{l}\text { Plans, Recommendations and } \\
\text { Awareness about the City }\end{array}$} & 1st grade & 102 & 2.625 & \multirow{5}{*}{0.215} \\
\hline & 2nd grade & 149 & 2.748 & \\
\hline & 3rd grade & 111 & 2.600 & \\
\hline & 4 th grade & 119 & 2.864 & \\
\hline & Graduate & 24 & 3.493 & \\
\hline \multirow{5}{*}{$\begin{array}{l}\text { Expectations from the Local } \\
\text { Government }\end{array}$} & 1st grade & 102 & 4.254 & \multirow{5}{*}{0.000} \\
\hline & 2 nd grade & 149 & 3.750 & \\
\hline & 3rd grade & 111 & 3.962 & \\
\hline & 4 th grade & 119 & 4.037 & \\
\hline & Graduate & 24 & 4.008 & \\
\hline \multirow{5}{*}{ Support in City Branding } & 1st grade & 102 & 3.578 & \multirow{5}{*}{0.003} \\
\hline & 2 nd grade & 149 & 3.481 & \\
\hline & 3rd grade & 111 & 3.386 & \\
\hline & 4 th grade & 119 & 3.697 & \\
\hline & Graduate & 24 & 3.741 & \\
\hline \multirow{5}{*}{$\begin{array}{l}\text { Natural Characteristic and Culture } \\
\text { of the City }\end{array}$} & 1st grade & 102 & 3.875 & \multirow{5}{*}{0.000} \\
\hline & 2nd grade & 149 & 3.671 & \\
\hline & 3rd grade & 111 & 3.672 & \\
\hline & 4 th grade & 119 & 3.899 & \\
\hline & Graduate & 24 & 4.875 & \\
\hline
\end{tabular}




\begin{tabular}{|c|c|c|c|c|}
\hline \multicolumn{2}{|l|}{ Income } & \multirow{2}{*}{$\frac{n}{128}$} & \multirow{2}{*}{$\begin{array}{l}\text { Mean } \\
3.835\end{array}$} & Homogeneity of Variances Sig. \\
\hline \multirow{5}{*}{$\begin{array}{l}\text { Expectations from the Local } \\
\text { Government }\end{array}$} & $1000 \mathrm{TL}$ and under & & & \multirow{5}{*}{0.105} \\
\hline & $1001-1500 \mathrm{TL}$ & 111 & 4.081 & \\
\hline & $1501-2000 \mathrm{TL}$ & 77 & 4.210 & \\
\hline & 2001-2500TL & 54 & 3.985 & \\
\hline & $2501 \mathrm{TL}$ and above & 133 & 4.016 & \\
\hline \multirow{5}{*}{$\begin{array}{l}\text { Event Organizations and Shopping } \\
\text { Options in the City }\end{array}$} & $1000 \mathrm{TL}$ and under & 128 & 2.600 & \multirow{5}{*}{0.576} \\
\hline & $1001-1500 \mathrm{TL}$ & 111 & 2.535 & \\
\hline & $1501-2000 \mathrm{TL}$ & 77 & 2.185 & \\
\hline & $2001-2500 T L$ & 54 & 2.629 & \\
\hline & $2501 \mathrm{TL}$ and above & 133 & 2.335 & \\
\hline \multicolumn{2}{|l|}{ Geographical Region } & $\mathrm{n}$ & Mean & Homogeneity of Variances Sig. \\
\hline \multirow{7}{*}{$\begin{array}{l}\text { Plans, Recommendations and } \\
\text { Awareness about the City }\end{array}$} & Marmara Region & 86 & 2.679 & \multirow{7}{*}{0.443} \\
\hline & Black Sea region & 171 & 2.972 & \\
\hline & Central Anatolia Region & 80 & 2.542 & \\
\hline & Aegean Region & 52 & 2.674 & \\
\hline & Mediterranean Region & 42 & 2.489 & \\
\hline & Eastern Anatolia Region & 22 & 2.521 & \\
\hline & Southeastern Anatolia Region & 21 & 2.692 & \\
\hline
\end{tabular}

Table 10 showed statistically significant differences between the students' ages and the dimensions of "Plans, Recommendations and Awareness about the City," "Expectations from the Local Government," "Support in City Branding," and "Natural Characteristic and Culture of the City." In this context, we observed that the most positive perception associated with these dimensions was reported by students of ages 24 and above.

Statistically significant differences were found between the students' years of higher education and the dimensions of "Plans, Recommendations and Awareness about the City," "Event Organizations and Shopping Options in the City" "Expectations from the Local Government," "Support in City Branding," and "Natural Characteristic and Culture of the City." In this context, we observed that the most positive perception associated with years of higher education was reported by the 4th-year university students for the "Expectations from the Local Government" dimension and that graduate students reported more positive perceptions about the other dimensions.

Moreover, another statistically significant difference was found between the income level of the participants and the dimensions of "Expectations from the Local Government" and "Event Organizations and Shopping Options in the City." In this context, the most positive perception about the "Expectations from the Local Government" was reported by the income level of $£ 2501$ and above; while the most positive perception about the "Event Organizations and Shopping Options in the City" dimension was reported by the income level between £2001-£2500.

Finally, a statistically significant difference was found between students' region of origin and the dimension of "Plans, Recommendations and Awareness about the City." Accordingly, it was found that the students coming from the Black Sea Region had the most positive perception about this dimension. 


\section{Conclusion}

Today's conditions make it important for any city to become a brand if it is to claim its share in the global marketplace. City branding is only possible if the characteristics of a city are valuable, and if such value is appreciated by the people. Moreover, university students play an important role in the creation of brand perception.

Making up a certain percent of the city population, university students contribute to the perceived city brand. Thanks to their familiarity with the city they study in, university students can offer unbiased opinions on the question if a city has a city brand or not. Nevertheless, the fact that the local population had all the time to build an emotional bond with the city they live in suggests that they are more likely to be biased about their reports about the perceived city brand when compared to the students. On the other hand, students contribute greatly to the perceived city brand as they can compare the city with their hometown, and it is safe to say that word to mouth advertising is a very effective marketing method which naturally occurs during and after the students' education.

This study aimed to explore the city brand of Kastamonu as perceived by the students of Kastamonu University and their perceptions were categorized under 7 factors identified for the city brand scale consisting of 40 statements. Among these factors are, as follows:

Factor 1: plans, recommendations and awareness about the city consists of a total number of 12 statements and its Cronbach's Alpha was found to be 0.937; factor 2: expectations from the local government consists of a total number of 5 statements and its Cronbach's Alpha was found to be 0.812 ; factor 3: event organizations and shopping options in the city consists of a total number of 7 statements including the following, and its Cronbach's Alpha was found to be 0.861 ; factor 4: support in city branding consists of a total number of 5 statements and its Cronbach's Alpha was found to be 0.873 ; factor 5 : locals consists of a total number of 4 statements and its Cronbach's Alpha was found to be 0.866; factor 6: natural characteristic and culture of the city consists of a total number of 3 statements and its Cronbach's Alpha was found to be 0.826 and factor 7: city planning consists of a total number of 3 statements including the following, and its Cronbach's Alpha was found to be 0.788 .

As a result of our analysis, we found statistically significant differences between parameters such as age and gender of the students, years of academic study, income, place of origin, previous knowledge about the city, first impression about the city and current opinion about the city with respect to these city branding dimensions.

According to the findings of this study, approximately half of the participants were knowledgeable about the city before their first visit. This finding suggests that the students who are currently studying or who had studied in this city share information about this city with others. Furthermore, it was found that more than half of the participants had a negative first impression about the city, but the majority (63.4\%) reported that they had a positive opinion about the city at the moment. This finding suggests that the students grew fond of the city as the time past, recognizing the valuable assets of Kastamonu. In this context, it would be fair to say that the city of Kastamonu moves on to build its own brand.

Comparative analysis based on students' gender showed that female participants perceived the nature and culture of the city more positively when compared to the male participants. Accordingly, it was concluded that female participants were more willing to support the city branding efforts, and that they expected the local government to show the same type of willingness in this respect. Among the dimensions which were perceived more positively by the male participants are, as follows: "Event Organizations and Shopping Options in the City" and 
"Locals." This finding suggests that male participants' expectation form a city brand is rather focused on shopping and entertainment and communication with the locals.

Research results showed that students had a positive perception of "Plans, Recommendations and Awareness about the City" if they were knowledgeable about the city before their first visit. In this context, it would be safe to conclude that students are likely to work and live in Kastamonu after graduation and they are likely to recommend this city to others, as they perceive it as a city brand. In parallel with this finding, we believe that the authorities should do their best to improve the city brand of Kastamonu as perceived by current students in order to ensure that newly enrolled students will have a positive perception about its city brand.

Statistically significant differences were found between positive reports on the statements of "first impression about the city" and "current opinion about the city" and all the dimensions but "Expectations from the Local Government." The fact that students had very positive perceptions about the city suggests that their expectations from the local government with regards to social and cultural facilities, transportation and promotion were not vital, and that they believe Kastamonu has a good standing in city branding as it is today.

We observed that 4 th year students, graduates and students of ages 24 and above had a relatively positive perception about the nature and culture of the city, therefore these students had higher expectations from the local government with respect to branding. On the other hand, the fact that students positively perceived the "Plans, Recommendations and Awareness About the City" dimension indicates that they already recognize Kastamonu as a city brand and it is likely that they could live and work in this city and recommended to the others. Moreover, we concluded that 4 th year students and graduates believe that shopping and entertainment centers of the city play an important role in the perceived city brand of Kastamonu.

The results showed that students with an income level of $£_{2501}$ and above have higher expectations from the local government with respect to improved social and cultural facilities, cleanliness, public transportation and promotion efforts when compared to other income brackets. It was further found that students with an income level between £2001-£2501 deemed with a relatively higher percentage that the shopping and entertainment facilities in the city were sufficient.

The results showed that the students coming from the Black Sea Region were more likely to consider Kastamonu as a city brand, to recommend this city to others, and to be willing to live in this city after they get their degree when compared to the students from other regions. The most likely explanation of this finding is the regional and ethnic similarities of the Black Sea Region and Kastamonu.

In conclusion, it would be safe to say that city branding is an important effort if it is for a city to claim its share in the global tourism market. In this respect, the contribution of university students to the branding of a city shouldn't be overlooked. According to the findings of our study, the Turkish city of Kastamonu moves on to become a city brand with the brand values it has to offer. In order to be successful in this process and to expedite it, improving the city brand as perceived by the students, asking for their advice, and appreciating their opinions will be of utmost importance. 


\section{References}

Aaker, J. (2009). Building Innovate Brands. Stanford Press, Stanford.

Ailawadi, Kusum L. ve Kevin L. Keller 2004. Understanding Retail Branding: Conceptual Insights and Research Priorities, Journal of Retailing 80, 331-342.

Altunbaş, H. 2007. Pazarlama İletişimi ve Şehir Pazarlaması "Şehirlerin Markalaşması", Selçuk Üniversitesi İletişim Fakültesi Akademik Dergisi 156-162.

Anholt, S. 2005. How The World Sees The World's Cities. Place Branding 2/1, 18.

Avcılar, M. Y. ve Kara, E. 2015. Şehir Markası Kavramı ve Marka Şehir Yaratma Stratejilerine Yönelik Literatür İncelemesi, Sosyal ve Beşeri Bilimler Araştırmaları Dergisi 34, 76-94.

Balcı, A. (1995). Sosyal Bilimlerde Araştırma. Ankara Üniversitesi Eğitim Bilimleri Fakültesi, Ankara.

Banger, G. (2006). Marka Olmak, http://www.gurcanbanger.com /yaz/esko491.htm,

Büyüköztürk, Ș. (2002). Sosyal Bilimler Için Veri Analiz El Kitabı. Pegem Yayıncılık, Ankara.

Büyüköztürk, Ş. (2010). Sosyal Bilimler için Veri Analizi El Kitabı, Pegem Akademi Yayıncılık, Ankara.

Can, M. C. ve Kazancı, Başaran, Z. (2014). Kent Markası ve İmajının Belirlenmesi: Rize Örneği. Marmara Üniversitesi Öneri Dergisi 11, 42.

Cevher, E. 2012. Kentsel Markalaşma Süreci: Antalya örneği. Sosyal ve Beşeri Bilimler Dergisi 4(1).

Ceylan, S. 2011. Destinasyon Marka İmajı Ve Pamukkale Yöresinde Bir Uygulama. Uluslararası Íktisadi ve İdari Incelemeler Dergisi 7.

Coşkun, R., Altunışık, R ve Yıldırım, E. (2017). Sosyal Bilimlerde Araştırma Yöntemleri Spss Uygulamalı. Sakarya Yayıncılık, Sakarya.

Çokluk, Ö., Şekercioğlu, G. ve Büyüköztürk, Ş. (2014). Sosyal Bilimler İçin Çok Değişkenli İstatistik: SPSS ve LISREL uygulamaları. Ankara: Pagem Akademi.

Dinnie, K. (2011). City Branding: Theory and Cases. Palgrave Macmillian Publisher Limited, Hampshire, UK.

Erdogan, H. (1996). Uluslararası Turizm. Uludağ Üniversitesi Basımevi, Bursa.

Fırat, A. ve Kömürcüoğlu, F. (2015). Muğla Şehir Markası Ve Imaj Algısı; Muğla Sitkı Koçman Üniversitesi Öğrencileri Üzerine Bir Alan Araştırması, Yönetim Bilimleri Dergisi 13, 26, 285-304.

Field, A. (200o). Discovering Statistics using SPSS for Windows. Thousand Oaks, London. Sage Publications, New Delhi.

Garaca, V., Jovanovic, G., ve Pejovic, L. (2011). Petrovaradin Fortress (Novi Sad, Serbia): Tourism Spatial Planning and Design of The Upper Town for the Function of Cultural Tourism, Turizam 15(2), 65-76.

Güler, Y. B. ve Gürer, A. 2015. Kent Marka Bağlılığına Yerel Katılım Eğiliminin Etkisini Belirlemeye Yönelik Bir Araştırma. İnsan ve Toplum Bilimleri Araştırmaları Dergisi-Journal of the Human and Social Science Researches 4(1), 64-82.

Hair, J. F., Anderson, R. E., Tatham, R. L. and Black, W. C. (1998). Multivariate Data Analysis, Fifth Edition. Prentice-Hall Inc., New Jersey.

Ilgüner, M. (2006). Türkiye'de Marka Yaratma ve Yaşatmanın Altın Kuralları. Rota Yayıncılık, İstanbul.

İri, R., İnal, M. E., ve Türkmen, H. H. 2011. Şehir Pazarlamasında Bilinirliğin Önemi: Niğde Yöresinin Bilinirliğinin Ölçülmesine Yönelik Bir Araştırma. Niğde Üniversitesi İIBF Dergisi 4, 1, 81-96. 
İslamoğlu, H. (2002). Pazarlama İlkeleri. Beta Yayınları, İstanbul.

Karagöz, Y. ve Kösterelioğlu, İ. 2008. İletişim Becerileri Değerlendirme Ölçeğinin Faktör Analizi Metodu ile Geliştirilmesi. Dumlupınar Üniversitesi Sosyal Bilimler Dergisi 21, 81-98.

Kavaratzis, M. 2009. What Can We Learn From City Marketıng Practıce?. European Spatial Research And Policy 16/1, 41-58.

Kaypak, Ş. 2013. Küreselleşme Sürecinde Kentlerin Markalaşması ve "Marka Kentler. C.Ü. İktisadi ve İdari Bilimler Dergisi 14, 1.

Kerlinger, F. N. (1978). Foundations Of Behavioral Research. McGraw Hill, New York.

Kline, R. B. (2011). Principles And Practice Of Structual Equation Modeling, Third Edition. The Guilford Press, New York.

Kotler, P. ve Gertner, D. 2002. Country As Brand, Product, And Beyond: A Place Marketing And Brand Management Perspective. Journal of Brand Management 9.

Kozak, M. (2014). Bilimsel Araştırma Tasarım, Yazım Ve Yayım Teknikleri. Detay Yayıncılık, Ankara.

Kozak, N. (2012). Turizm Bilgisi. Anadolu Üniversitesi Web Tesisleri, Eskişehir.

Kozak, N. (2014). Turizm Pazarlaması, (6. Bask1). Detay Yayıncılık, Ankara.

Malhotra, N. (1996). Marketing Research -An Applied Orientation, Second Edition. Prentice Hall Internetional.

Manic, Z., ve Backovic, V. 2010. Arhitektura Moderne u Fuknciji Promocije Beograda. Arhitektura i Urbanizam 30, 47-51.

Özdemir, Ş. ve Karaca, Y. 2009. Kent Markası ve Marka İmajının Ölçümü: Afyonkarahisar Kenti İmajı Üzerine Bir Araştırma. Afyon Kocatepe Üniversitesi, İ.I.B.F. Dergisi 11(2), 113134.

Paunović, I. 2014. Branding Serbia As A Tourist Destination On The Global Market. Turizam 18(2), 59-71.

Peker, A.E. (2006). Kentlerin Markalașma Sürecinde Çağdaș Sanat Müzelerinin Rolü: Kent Markalaşması ve Küresel Landmark. İstanbul Teknik Üniversitesi, Fen Bilimleri Enstitüsü, Yüksek Lisans Tezi.

Perry, A. ve Wisnom, D. (2003). Markanın DNA'sı, Eşsiz ve Dayanıklı Markalar Yaratmanın Kuralları. Çeviren: Zeynep Yılmaz. Mediacat Kitapları, İstanbul.

Porter, M. E. (1985). Competitive Advantage: Creating And Sustaining Superior Performance. Free Press, New York.

Rainisto, S. K. (2003). Success Factors Of Place Marketing: A Study of Place Marketing Practice In Northern Europe And United States. Helsinki University of Technology, Institute of Strategy and International Business Doctoral Dissertations 2003/4, Helsinki.

Saran, M. 2005. Kent Pazarlaması: Güçlü Bir Kent İmajı ve Kent Markası Oluşturmak. TMMOB Makine Müh. Odası, Marka Yönetimi Sempozyumu зо.

Tek, M. 2009. Kamu Yatırımlarında Turizmin Yeri, Türkiye Turizm Stratejisi 2023'de Marka Kentler Projesi: Eleștirel Bir Değerlendirme. Anatolia: Turizm Araştırmaları Dergisi, 20, 2, Bahar, 169-184.

Tek, Ö.,B. (2005). Modern Pazarlama İlkeleri. Birleşik Matbaacılık, İzmir.

The Knihgt Frank, (2014). The Wealth Report 2014, a Global Perspective on Prime Property and Wealth, 03.02.2015, (http://www.thewealthreport.net/global- cities/default.aspx.

Ülgen, H. ve Mirze, S., K. (2006). İsletmelerde Stratejik Yönetim, (3. Baskı). Literatür Yayıncılık, İstanbul.

Yediyıldız, B. (1994). Tarih, (II. Cilt). MEB Yayınları, İstanbul.

Yuen, B. 2005. Searching For Place Identity In Singapore, Habitat International 29, 197-214. 
Yüksel A. ve M., Kara, E. 2015. Şehir Markası Kavramı ve Marka Şehir Yaratma Stratejilerine Yönelik Literatür İncelemesi. Sosyal Ve Beşerî Bilimler Araştırmaları Dergisi, 34.

Yüksel, A. M. ve İnci Varinli (2013). Perakende Marka Değerinin Ölçümü ve Yapısal Eşitlik Modeli Uygulaması, 1. Baskı. Detay Yayıncılık, Ankara.

URL1. http://www.kastamonukultur.gov.tr/TR,63867/tarihi-evler-ve-konaklar.html (Erişim Tarihi: 15.10 .2017$)$.

URL2. http://www.temelaksoy.com/marka-sehirler/ (Erişim Tarihi:18.10.2017).

Watkins, H. ve Herbert, D. 2003. Cultural Policy And Place Promotion: Swansea And Dylan Thomas, Geoforum 34, 249-26. 